\title{
Early metabolic defects following gestational diabetes in three ethnic groups of anti-GAD antibodies negative women with normal fasting glucose
}

\author{
Eleni Kousta ${ }^{1}$, Natasha J. Lawrence ${ }^{1}$, Ian F. Godsland ${ }^{1}$, Anna Penny ${ }^{1}$, Victor Anyaoku ${ }^{1}$, \\ Barbara A. Millauer ${ }^{1}$, Stephen Robinson ${ }^{1}$, Desmond G. Johnston ${ }^{1}$, Mark I. McCarthy ${ }^{1,2}$ \\ ${ }^{1}$ Section of Endocrinology and Metabolic Medicine, ${ }^{2}$ Imperial College Genetics and Genomics Research Institute, \\ Imperial College Faculty of Medicine, St. Mary's Hospital, Norfolk Place, London W2 1PG, U.K.
}

\begin{abstract}
OBJECTIVE: To characterise early metabolic abnormalities and the impact of ethnicity following gestational diabetes mellitus (GDM). DESIGN: Women with a history of GDM belonging to three different ethnic groups were evaluated. Using the insulin-modified, frequently-sampled intravenous glucose tolerance test (FSIVGTT) and HOMA we studied 34 European, 16 South Asian and 10 Afro-Caribbean women with normal fasting glucose following GDM and 44 European, 16 South Asian and 19 Afro-Caribbean controls to assess insulin action and secretion. RESULTS: European post-GDM women had lower insulin sensitivity by FSIVGTT [0.6 (0.1-5.1) vs $1.5(0.8-2.8) \times 10^{-4} \cdot \mathrm{min}^{-1} \cdot \mathrm{pmol}^{-1 \cdot} \cdot \mathrm{l}^{-1}, \mathrm{p}=0.010$, adjusted for BMI $\left.\mathrm{p}=0.054\right]$ and by HOMA [72(22-235) vs 153(55-421)\%, $p=0.004$, adjusted for $B M I p=0.006]$, and reduced $\beta$-cell function [lower disposition index $0.05(0.01-0.40)$ vs $0.11(0.05-0.25) \mathrm{min}^{-1}, \mathrm{p}=0.017$ ] compared with controls. South Asian post-GDM women had decreased $\beta$-cell function [lower HOMA (\%B) (73 (37-147) vs $124(59-262) \%, p=0.048$ and acute insulin response to glucose $(463)(131-1639)$ vs 1039 (393-2748) $\mathrm{pmol} / \mathrm{l} \mathrm{h}, \mathrm{p}=\mathbf{0 . 0 5 2}]$ than controls. Afro-Caribbean post-GDM women had lower glucose disappearance rate $\left[1.3(0.6-2.8)\right.$ vs $\left.2.6(1.8-3.8) 10^{-2} / \mathrm{min}, \mathrm{p}=0.003\right]$ than controls, suggesting subtle glucose intolerance. CONCLUSIONS: Women with a history of GDM of three different ethnic groups, even in the presence of normal fasting glucose, display a range of metabolic abnormalities, including $\beta$-cell dysfunction with variable insulin resistance. These derangements may be influenced by ethnicity.
\end{abstract}

Key words: Ethnicity, Gestational diabetes, Metabolic defects

Address for correspondence:

Dr Eleni Kousta, 6 S. Arvanitaki str, Corfu 49100, Greece,

Tel: +30 26610 80561, Fax: +3026610 80562,

e-mail:1kousta@otenet.gr

Received 27-11-06, Revised 12-03-07, Accepted 25-03-07
This study was funded by a project grant from the U.K. Medical Research Council and through support from the Joint Research Standing Committee at St Mary's Hospital. I.F.G. is supported by the Heart Disease and Diabetes Research Trust. 


\section{INTRODUCTION}

Gestational diabetes (GDM) is defined as carbohydrate intolerance first recognised in pregnancy. ${ }^{1}$ Although the majority of women with GDM return to normal glucose tolerance after delivery, they remain, as a group, at substantially increased risk of developing type 2 diabetes in later life. ${ }^{2,3}$ GDM may therefore be considered a forerunner of type 2 diabetes and the study of women in the post-GDM state serves as a model for detection of early metabolic abnormalities associated with subsequent disease progression.

Ethnicity influences the prevalence of GDM, being higher in non-European populations. ${ }^{4,5}$ In addition, the progression to permanent type 2 diabetes may occur more rapidly in non-European subjects. ${ }^{2,6}$ Ethnic variations in insulin sensitivity, blood pressure and aspects of the Metabolic Syndrome have also been described, independently of GDM. ${ }^{7,8}$

Whilst insulin action and secretion are both clearly impaired during pregnancies complicated by GDM, the extent and nature of the metabolic disturbances persisting after pregnancy remain unclear. Even when the confounding effects of hyperglycaemia are avoided by studying women with a history of GDM who have normal glucose tolerance postpartum, conflicting conclusions have been reached. ${ }^{9-11}$ Some of these disparities may have resulted from the study of small numbers of subjects tested and of mixed ethnic origin.

We previously found, using the insulin-modified frequently-sampled intravenous glucose tolerance test (FSIVGTT), a range of metabolic abnormalities, including insulin resistance, reduced $\beta$-cell function and dyslipidaemia in women of exclusively European origin with previous gestational diabetes. ${ }^{12}$ Given the ethnic variations in insulin sensitivity and metabolic aspects, we wanted to assess whether similar metabolic abnormalities persist following gestational diabetes in other ethnic groups. We investigated insulin action and secretion by using the FSIVGTT and HOMA model following gestational diabetes in a group of South Asian and Afro-Caribbean women with normal fasting glucose and present these findings together with our previously studied European group.

\section{SUBJECTS}

Over a two-year period, 34 European, 16 South Asian and 10 Afro-Caribbean women with previous GDM were retrospectively recruited from West London antenatal databases (Table 1). Although the clinical criteria and protocols used for diagnosis and treatment of GDM in different recruitment centres vary to a limited extent, only women who fulfilled WHO (1999) criteria for glucose intolerance during pregnancy (glucose $>7.8 \mathrm{mmol} / \mathrm{l}$ following $75 \mathrm{~g}$ of glucose) were considered to have had proven GDM for the purposes of this study. ${ }^{13}$ All women were invited to attend for a standardized clinical examination which included anthropometry and a $75 \mathrm{~g}$ oral glucose tolerance test (OGTT) to assess current (i.e. postpartum) glucose homeostasis. Body mass index (BMI), calculated as weight $(\mathrm{kg}) /$ height(metres) ${ }^{2}$, and waist (the least circumference between the costal margin and the iliac crest) to hip (the circumference at the level of the greater trochanters) ratio were recorded. Where the OGTT could not be completed (in 2 European, 6 South Asian and 5 Afro-Caribbean subjects), a fast-

Table 1. Characteristics of the studied subjects

\begin{tabular}{|c|c|c|c|c|c|c|}
\hline & \multicolumn{2}{|c|}{ European women } & \multicolumn{2}{|c|}{ South Asian women } & \multicolumn{2}{|c|}{ Afro-Caribbean women } \\
\hline & $\begin{array}{c}\text { Post-GDM } \\
(n=34)\end{array}$ & $\begin{array}{c}\text { Control women } \\
(n=44)\end{array}$ & $\begin{array}{c}\text { Post-GDM } \\
(n=16)\end{array}$ & $\begin{array}{c}\text { Control women } \\
(n=16)\end{array}$ & $\begin{array}{c}\text { Post-GDM } \\
(n=10)\end{array}$ & $\begin{array}{c}\text { Control women } \\
(n=19)\end{array}$ \\
\hline Age (years) & $\begin{array}{c}37.4 \\
(32.6-43.0)\end{array}$ & $\begin{array}{c}35.2 \\
(29.9-41.4)\end{array}$ & $\begin{array}{c}32.7 \\
(26.1-40.9)\end{array}$ & $\begin{array}{c}32.5 \\
(25.8-40.9)\end{array}$ & $\begin{array}{c}34.7 \\
(30.7-39.3)\end{array}$ & $\begin{array}{c}34.4 \\
(29.8-39.9)\end{array}$ \\
\hline $\begin{array}{l}\text { Time since delivery } \\
\text { (months) }\end{array}$ & $\begin{array}{c}24 \\
(10-55)\end{array}$ & $\begin{array}{c}27 \\
(14-50)\end{array}$ & $\begin{array}{c}14 \\
(6-31)\end{array}$ & $\begin{array}{c}17 \\
(7-43)\end{array}$ & $\begin{array}{c}25 \\
(11-53)\end{array}$ & $\begin{array}{c}27 \\
(12-60)\end{array}$ \\
\hline Parity & $\begin{array}{c}2 \\
(1-3)\end{array}$ & $\begin{array}{c}2 \\
(1-3)\end{array}$ & $\begin{array}{c}2 \\
(1-3)\end{array}$ & $\begin{array}{c}2 \\
(1-4)\end{array}$ & $\begin{array}{c}2 \\
(1-4)\end{array}$ & $\begin{array}{c}2 \\
(1-3)\end{array}$ \\
\hline
\end{tabular}

Data are presented as geometric mean (SD range). 
ing plasma glucose and an $\mathrm{HbA1c}$ were performed. Based on these measures, interpreted according to WHO (1999) criteria using all available results, ${ }^{13}$ all women had normal glucose homeostasis at the time of the metabolic studies. Autoimmune diabetes was excluded on the basis of measurement of anti-GAD antibody titre. ${ }^{14}$

Over the same period, 44 European, 16 South Asian and 19 Afro-Caribbean control women were recruited retrospectively from the same sources. All these women had successfully passed the modified O'Sullivan screening test ${ }^{15}$ during the most recent pregnancy and had maintained normal glucose levels throughout all previous pregnancies. In addition, all control subjects had a normal fasting glucose according to WHO (1999) criteria $^{13}$ and a normal HbA1c at the time of this study. There was no family history of type 2 diabetes in 1st degree relatives in any of the women.

The two groups were matched for ethnicity, age, parity and time since delivery (Table 1). Parents' and grand-parents' place of birth, language and religion were documented to ensure that recruitment in both groups was restricted to subjects with exclusively European, South Asian and Afro-Caribbean ancestry for at least 3 generations. No woman in either group was pregnant or breast-feeding at the time of the study. All subjects were assessed in the follicular part of their cycle, or in the "pill-free" interval for those receiving oral contraceptives.

The study protocol had been approved by the local ethics committee for each recruitment hospital. Informed consent was obtained from all subjects studied.

\section{METHODS}

\section{Frequently sampled intravenous glucose tolerance test (FSIVGTT)}

An insulin modified FSIVGTT was used to estimate insulin sensitivity $\left(\mathrm{S}_{\mathrm{i}}\right)$ and glucose effectiveness $\left(\mathrm{S}_{\mathrm{g}}\right)$ from glucose and insulin data by the minimal model method of Bergman. ${ }^{16,17}$ After an overnight fast, an intravenous line was inserted in each antecubital fossa. A glucose bolus $(0.3 \mathrm{~g} / \mathrm{kg}$ of body weight, $50 \%$ dextrose solution) was administered intravenously over one minute and 25 minutes later insulin was injected at a dose of $0.02 \mathrm{U} / \mathrm{kg}$ of body weight. Serum intact insulin and plasma glucose were measured in samples taken 15 minutes before and immediately before glucose injection. Blood samples for insulin and plasma glucose measurements were taken at: 2, 3, 4, 5, 6, 8, $10,12,14,16,19,22,24,26,27,28,29,30,32,35,38$, $40,50,60,70,80,90,100,120,140,160$ and $180 \mathrm{~min}$ after the intravenous glucose administration, from the other arm. The minimal model parameters, $S_{i}$ and $S_{g}$, were derived using the IS-CIBA computer package (Gunther Mehring, Novartis Pharmaceuticals, Basel, Switzerland). Glucose disappearance rate $\left(\mathrm{K}_{\mathrm{g}}\right)$ was calculated as the slope of glucose decline from 10 to 24 min of the FSIVGTT and acute insulin response to glucose $\left(\mathrm{AIR}_{\mathrm{g}}\right)$ was assessed as the incremental area under the curve (AUC) (calculated by the trapezoid rule) from 2 to $10 \mathrm{~min}$ of the FSIVGTT. ${ }^{18}$ Of the 139 FSIVGTTs, data from 3 subjects (2 European women with previous GDM and 1 European control woman) could not be satisfactorily modelled. Therefore, there are no estimates for $S_{i}$ and $S_{g}$ for these 3 subjects. The disposition index $\left(\mathrm{S}_{\mathrm{i}} \mathrm{x} \mathrm{AIR}_{\mathrm{g}}\right)$, an index of $\beta$-cell function which takes account of prevailing insulin sensitivity and which exploits the hyperbolic relationship between the two, ${ }^{19,20}$ was calculated by the method described by Kahn et al. ${ }^{20}$

\section{HOMA}

Fasting glucose and specific insulin measures (the average from 2 samples taken with a 15 minute collection interval) were used to derive estimates of $\beta$-cell function (\%B) and insulin sensitivity $(\% \mathrm{~S})$ using the "homeostasis model assessment" (HOMA). ${ }^{21}$ HOMA-derived parameters have been shown to correlate well with other measures of insulin resistance and $\beta$-cell function. ${ }^{22,23}$

\section{Biochemical assays}

Glucose and lipid parameters were measured enzymatically on the Olympus AU5200 analyser (Olympus Opticals UK Ltd.). HDL-cholesterol levels were assayed following selective precipitation of non-HDL lipoproteins using dextran sulphate and magnesium. Specific insulin levels were measured by ELISA, using an assay with a sensitivity of $0.55 \mathrm{pmol} / \mathrm{l}$ and inter-assay variation not exceeding $8.6 \%$ at low and high values. ${ }^{24}$ The cross-reactivity of proinsulin 
with the intact insulin assay is negligible.

\section{Statistical analysis}

Since the distribution of variables was not normal, we log-transformed data to achieve normality. Data are presented as geometric mean (SD range). Statistical analyses were performed in SPSS 8.0 for Windows using unpaired Student's t-test and analysis of variance, as appropriate, on log-transformed data. Repeat analysis was performed incorporating: a. BMI as a covariate and b. BMI, age, parity and time since delivery as covariates.

\section{RESULTS}

European women with previous GDM displayed clinical and metabolic abnormalities compared to European control women: significantly higher BMI ( $\mathrm{p}$-value $=0.033)$, waist $/$ hip $(\mathrm{p}$-value $=0.001)$, fasting triglycerides $(\mathrm{p}$-value $=0.001)$, fasting insulin $(\mathrm{p}$ value $=0.004)$ and lower HDL-cholesterol ( $p$-value $=0.024$ ) (Table 2 ). Allowing for BMI and additional analysis allowing for BMI, age, time since delivery and parity, reduced but did not abolish differences between the groups; apart from HDL-cholesterol, all remained statistically significant (Table 2). Insulin sensitivity was significantly lower in women with a history of GDM compared to controls as suggested by the lower HOMA $(\% \mathrm{~S})(\mathrm{p}$-value $=0.004$, adjusted for BMI p-value, was 0.006; adjusted for BMI, age, time since delivery and parity the p-value was 0.003 ). Insulin sensitivity $\left(\mathrm{S}_{\mathrm{i}}\right)$ derived from the FSIVGTT was lower [ $p$-value $=0.010$, adjusted for BMI $p$-value, was suggestive (borderline) $=0.054$, and adjusted for BMI, age, time since delivery and parity the p-value was 0.051 ] in the post-GDM group. Although $\beta$-cell function was higher in the basal state in the postGDM group, as suggested by higher HOMA $(\% \mathrm{~B})$ ( $\mathrm{p}$-value $=0.013$, adjusted for BMI, the p-value was 0.015; adjusted for BMI, age, time since delivery and parity the p-value was 0.007$)$, the disposition index was lower ( $\mathrm{p}$-value $=0.017$ ), suggesting $\beta$-cell dysfunction following glucose stimulation in the postGDM group (Table 2). Since the disposition index represents a measure of $\beta$-cell function, which already takes account of prevailing insulin sensitivity, we did not perform analyses that adjusted disposition index for measures of adiposity. There was no difference in glucose effectiveness $\left(\mathrm{S}_{\mathrm{g}}\right)$, acute insulin response $\left(\mathrm{AIR}_{\mathrm{g}}\right)$ and glucose disappearance rate $\left(\mathrm{K}_{\mathrm{g}}\right)$ between the two groups.

In South Asian women there was no statistically significant difference in BMI, waist/hip ratio, fasting lipids, fasting insulin and fasting glucose between the GDM and the control group (Table 3). There was no statistically significant difference in insulin sensitivity derived by both HOMA $(\% \mathrm{~S})$ and the FSIVGTT $\left(\mathrm{S}_{\mathrm{i}}\right)$ between post-GDM and control women; however, South Asian post-GDM women displayed lower $\beta$-cell $\operatorname{HOMA}(\% \mathrm{~B})(\mathrm{p}$-value $=0.048)$ and borderline-lower $\mathrm{AIR}_{\mathrm{g}}$ (p-value $\left.=0.052\right)$, suggesting decreased $\beta$-cell function (Table 3). After adjustment for BMI and for BMI, age, time since delivery and parity, these differences became suggestive ( $\mathrm{p}$-values of borderline significance) of decreased $\beta$-cell function (Table 3 ). There was no significant difference in $\mathrm{S}_{\mathrm{g}}, \mathrm{K}_{\mathrm{g}}$ and the disposition index between the two groups.

In Afro-Caribbean women there was no statistically significant difference in BMI, fasting lipids, fasting insulin and fasting glucose between the GDM and the control group, but post-GDM women displayed significantly higher waist/hip ratio than control women (Table 4). There was no statistically significant difference in insulin sensitivity and $\beta$-cell function, derived by FSIVGTT ( $\mathrm{S}_{\mathrm{i}}, \mathrm{AIR}_{\mathrm{g}}$ and disposition index) and HOMA ( $\% \mathrm{~S}$ and $\% \mathrm{~B})$ or $\mathrm{S}_{\mathrm{g}}$, but $\mathrm{K}_{\mathrm{g}}$ derived by the FSIVGTT was significantly lower in the GDM group compared to Afro-Caribbean control women ( $\mathrm{p}$-value $=0.003$, adjusted for BMI $p$-value $=0.003$ and adjusted for BMI, age, time since delivery and parity p-value $=0.006$ ), suggesting subtle glucose intolerance in the Afro-Caribbean post-GDM women (Table 4).

Figure 1 shows a plot of the disposition index, which is a very sensitive measure of $\beta$-cell function, in the three ethnic groups of GDM and control women. Although the disposition index is significantly lower only among the GDM European women compared to the control group, the tendency is similar in the other two ethnic groups.

\section{DISCUSSION}

We studied a group of European, South Asian and Afro-Caribbean women with a history of GDM, a population known to be at increased risk of devel- 
Table 2. Comparison of clinical, baseline biochemical data and parameters derived from the HOMA model and the FSIVGTT in European women with a history of GDM and control subjects.

\begin{tabular}{|c|c|c|c|c|c|}
\hline & $\begin{array}{c}\text { Post-GDM } \\
(\mathbf{n}=34)\end{array}$ & $\begin{array}{c}\text { Control women } \\
(n=44)\end{array}$ & p-value & $\begin{array}{l}\text { p-value with BMI } \\
\text { as covariate }\end{array}$ & $\begin{array}{l}\text { p-value with BMI, } \\
\text { age, parity and time } \\
\text { since delivery } \\
\text { as covariates }\end{array}$ \\
\hline $\begin{array}{l}\mathrm{BMI} \\
\left(\mathrm{kg} / \mathrm{m}^{2}\right)\end{array}$ & $\begin{array}{c}25.3 \\
(20.9-30.8)\end{array}$ & $\begin{array}{c}23.1 \\
(19.3-27.6)\end{array}$ & 0.033 & & \\
\hline Waist/Hip ratio & $\begin{array}{c}0.81 \\
(0.74-0.88)\end{array}$ & $\begin{array}{c}0.76 \\
(0.71-0.82)\end{array}$ & 0.001 & 0.011 & 0.010 \\
\hline $\begin{array}{l}\text { F. Cholesterol } \\
(\mathrm{mmol} / \mathrm{l})\end{array}$ & $\begin{array}{c}4.5 \\
(3.9-5.2)\end{array}$ & $\begin{array}{c}4.3 \\
(3.7-5.2)\end{array}$ & 0.247 & 0.599 & 0.670 \\
\hline $\begin{array}{l}\text { F. Triglycerides } \\
(\mathrm{mmol} / \mathrm{l})\end{array}$ & $\begin{array}{c}1.0 \\
(0.7-1.5)\end{array}$ & $\begin{array}{c}0.7 \\
(0.5-1.1)\end{array}$ & 0.001 & 0.005 & 0.005 \\
\hline $\begin{array}{l}\text { F. HDL-Cholesterol } \\
(\mathrm{mmol} / \mathrm{l})\end{array}$ & $\begin{array}{c}1.2 \\
(0.9-1.6)\end{array}$ & $\begin{array}{c}1.3 \\
(1.1-1.6)\end{array}$ & 0.024 & 0.149 & 0.142 \\
\hline $\begin{array}{l}\text { F. Glucose } \\
(\mathrm{mmol} / \mathrm{l})\end{array}$ & $\begin{array}{c}5.3 \\
(4.8-5.8)\end{array}$ & $\begin{array}{c}5.1 \\
(4.6-5.5)\end{array}$ & 0.069 & 0.162 & 0.222 \\
\hline $\begin{array}{l}\text { F. Insulin } \\
(\mathrm{pmol} / \mathrm{l})\end{array}$ & $\begin{array}{c}63 \\
(19-210)\end{array}$ & $\begin{array}{c}30 \\
(11-83)\end{array}$ & 0.004 & 0.006 & 0.003 \\
\hline $\begin{array}{l}\beta \text {-cell function-HOMA model } \\
(\% \mathrm{~B})\end{array}$ & $\begin{array}{c}107 \\
(48-236)\end{array}$ & $\begin{array}{c}70 \\
(35-139)\end{array}$ & 0.013 & 0.015 & 0.007 \\
\hline $\begin{array}{l}\text { Insulin sensitivity-HOMA model } \\
(\% \mathrm{~S})\end{array}$ & $\begin{array}{c}72 \\
(22-235)\end{array}$ & $\begin{array}{c}153 \\
(55-421)\end{array}$ & 0.004 & 0.006 & 0.003 \\
\hline $\begin{array}{l}\mathrm{S}_{\mathrm{i}} \\
\left(10^{4} / \mathrm{min} / \mathrm{pmol} / \mathrm{l}\right)\end{array}$ & $\begin{array}{c}0.6 \\
(0.1-5.1) \\
\mathrm{n}=32\end{array}$ & $\begin{array}{c}1.5 \\
(0.8-2.8) \\
\mathrm{n}=43\end{array}$ & 0.010 & 0.054 & 0.051 \\
\hline $\begin{array}{l}\mathrm{S}_{\mathrm{g}} \\
\left(10^{-2} / \mathrm{min}\right)\end{array}$ & $\begin{array}{c}1.7 \\
(1.1-2.7) \\
n=32\end{array}$ & $\begin{array}{c}2.0 \\
(1.2-3.5) \\
\mathrm{n}=43\end{array}$ & 0.193 & 0.244 & 0.181 \\
\hline $\begin{array}{l}\mathrm{K}_{\mathrm{g}} \\
\left(10^{-2} / \mathrm{min}\right)\end{array}$ & $\begin{array}{c}1.5 \\
(1.0-2.2)\end{array}$ & $\begin{array}{c}1.7 \\
(0.9-3.2)\end{array}$ & 0.192 & 0.166 & 0.157 \\
\hline $\begin{array}{l}\mathrm{AIR}_{\mathrm{g}} \\
(\mathrm{pmol} / \mathrm{h})\end{array}$ & $\begin{array}{c}735 \\
(255-2120)\end{array}$ & $\begin{array}{c}767 \\
(359-1638)\end{array}$ & 0.850 & 0.565 & 0.868 \\
\hline Disposition index & $\begin{array}{c}0.05 \\
(0.01-0.40)\end{array}$ & $\begin{array}{c}0.11 \\
(0.05-0.25)\end{array}$ & 0.017 & & \\
\hline
\end{tabular}

F: Fasting, $\mathrm{S}_{\mathrm{i}}$ : Insulin sensitivity, $\mathrm{S}_{\mathrm{g}}$ : Glucose effectiveness, $\mathrm{K}_{\mathrm{g}}$ : Glucose disappearance rate, AIRg: Acute insulin response to glucose Data are presented as geometric mean (SD range).

oping type 2 diabetes in later life. ${ }^{2}$ In order to avoid the confounding effects of hyperglycaemia (and/or its treatment) on the intermediate metabolic traits, we restricted our analysis to women with normal glucose homeostasis postpartum, focussing therefore on the subset of women with previous GDM likely to have the least marked metabolic defects..$^{25,26}$ These women were matched for ethnicity, parity and time since delivery with a group of control women. The insulin- modified, Bergman minimal modelling approach, used in our study, is a well-validated, commonly-employed procedure, which has the advantage of evaluating simultaneously insulin sensitivity and secretion..$^{16,17,27}$ We found that the women with a history of gestational diabetes of three different ethnic groups, even when they have normal fasting glucose, display metabolic abnormalities, including $\beta$-cell dysfunction with variable insulin resistance. 
Table 3. Comparison of clinical, baseline biochemical data and parameters derived from the HOMA model and the FSIVGTT in South Asian women with a history of GDM and control subjects.

\begin{tabular}{|c|c|c|c|c|c|}
\hline & $\begin{array}{l}\text { Post- GDM } \\
\quad(\mathrm{n}=16)\end{array}$ & $\begin{array}{l}\text { Control women } \\
(\mathbf{n}=16)\end{array}$ & p-value & $\begin{array}{l}\text { p-value with BMI } \\
\text { as covariate }\end{array}$ & $\begin{array}{l}\text { p-value with BMI, } \\
\text { age, parity and time } \\
\text { since delivery } \\
\text { as covariates }\end{array}$ \\
\hline $\begin{array}{l}\text { BMI } \\
\left(\mathrm{kg} / \mathrm{m}^{2}\right)\end{array}$ & $\begin{array}{c}26.7 \\
(22.0-32.4)\end{array}$ & $\begin{array}{c}27.2 \\
(22.5-32.8)\end{array}$ & 0.798 & & \\
\hline Waist/Hip ratio & $\begin{array}{c}0.83 \\
(0.74-0.93)\end{array}$ & $\begin{array}{c}0.86 \\
(0.75-0.98)\end{array}$ & 0.517 & 0.732 & 0.697 \\
\hline $\begin{array}{l}\text { F. Cholesterol } \\
(\mathrm{mmol} / \mathrm{l})\end{array}$ & $\begin{array}{c}4.7 \\
(4.0-5.4)\end{array}$ & $\begin{array}{c}4.5 \\
(3.8-5.4)\end{array}$ & 0.548 & 0.562 & 0.365 \\
\hline $\begin{array}{l}\text { F. Triglycerides } \\
(\mathrm{mmol} / \mathrm{l})\end{array}$ & $\begin{array}{c}1.2 \\
(0.8-1.9)\end{array}$ & $\begin{array}{c}1.2 \\
(0.7-2.2)\end{array}$ & 0.900 & 0.782 & 0.477 \\
\hline $\begin{array}{l}\text { F. HDL-Cholesterol } \\
(\mathrm{mmol} / \mathrm{l})\end{array}$ & $\begin{array}{c}1.0 \\
(0.8-1.3)\end{array}$ & $\begin{array}{c}0.9 \\
(0.8-1.2)\end{array}$ & 0.333 & 0.348 & 0.339 \\
\hline $\begin{array}{l}\text { F. Glucose } \\
(\mathrm{mmol} / \mathrm{l})\end{array}$ & $\begin{array}{c}5.4 \\
(4.8-6.0)\end{array}$ & $\begin{array}{c}5.1 \\
(4.8-5.5)\end{array}$ & 0.088 & 0.052 & 0.080 \\
\hline $\begin{array}{l}\text { F. Insulin } \\
(\mathrm{pmol} / \mathrm{l})\end{array}$ & $\begin{array}{c}39 \\
(14-106)\end{array}$ & $\begin{array}{c}72 \\
(24-210)\end{array}$ & 0.109 & 0.120 & 0.173 \\
\hline $\begin{array}{l}\beta \text {-cell function-HOMA model } \\
(\% \mathrm{~B})\end{array}$ & $\begin{array}{c}73 \\
(37-147)\end{array}$ & $\begin{array}{c}124 \\
(59-262)\end{array}$ & 0.048 & 0.054 & 0.059 \\
\hline $\begin{array}{l}\text { Insulin sensitivity-HOMA model } \\
(\% \mathrm{~S})\end{array}$ & $\begin{array}{c}115 \\
(43-309)\end{array}$ & $\begin{array}{c}64 \\
(22-185)\end{array}$ & 0.120 & 0.131 & 0.167 \\
\hline $\begin{array}{l}\mathrm{S}_{\mathrm{i}} \\
\left(10^{4} / \mathrm{min} / \mathrm{pmol} / \mathrm{l}\right)\end{array}$ & $\begin{array}{c}0.7 \\
(0.2-3.1)\end{array}$ & $\begin{array}{c}0.5 \\
(0.1-2.8)\end{array}$ & 0.490 & 0.527 & 0.720 \\
\hline $\begin{array}{l}\mathrm{S}_{\mathrm{g}} \\
\left(10^{-2} / \mathrm{min}\right)\end{array}$ & $\begin{array}{c}1.7 \\
(1.4-2.2)\end{array}$ & $\begin{array}{c}2.3 \\
(1.1-4.9)\end{array}$ & 0.167 & 0.112 & 0.096 \\
\hline $\begin{array}{l}\mathrm{K}_{\mathrm{g}} \\
\left(10^{-2} / \mathrm{min}\right)\end{array}$ & $\begin{array}{c}1.7 \\
(1.2-2.3)\end{array}$ & $\begin{array}{c}2.2 \\
(1.4-3.3)\end{array}$ & 0.056 & 0.050 & 0.068 \\
\hline $\begin{array}{l}\mathrm{AIR}_{\mathrm{g}} \\
(\mathrm{pmol} / \mathrm{lh})\end{array}$ & $\begin{array}{c}463 \\
(131-1639)\end{array}$ & $\begin{array}{c}1039 \\
(393-2748)\end{array}$ & 0.052 & 0.057 & 0.061 \\
\hline Disposition index & $\begin{array}{c}0.03 \\
(0.01-0.17)\end{array}$ & $\begin{array}{c}0.05 \\
(0.01-0.30)\end{array}$ & 0.531 & & \\
\hline
\end{tabular}

F: Fasting, $\mathrm{S}_{\mathrm{i}}$ Insulin sensitivity, $\mathrm{S}_{\mathrm{g}}$ : Glucose effectiveness, $\mathrm{K}_{\mathrm{g}}$ : Glucose disappearance rate, AIRg: Acute insulin response to glucose Data are presented as geometric mean (SD range).

European women with a history of GDM displayed clinical and metabolic abnormalities compared to control women: central obesity, dyslipidaemia, hyperinsulinaemia and insulin resistance, as previously described in detail. ${ }^{12}$ These differences persisted after allowing for the differences in BMI between the groups, except for HDL-Cholesterol and the difference in $\mathrm{S}_{\mathrm{i}}$, which were of reduced-to-borderline significance. Also, although HOMA $(\% \mathrm{~B})$ was increased in the post-GDM group, indicating increased $\beta$-cell function in the basal state, the FSIVGTT-derived disposi- tion index showed reduced $\beta$-cell function following glucose stimulation, suggesting reduced functional capacity of the $\beta$-cell. Among the South Asian group there was no difference in insulin sensitivity derived either by HOMA $(\% \mathrm{~S})$ or the FSIVGTT $\left(\mathrm{S}_{\mathrm{i}}\right)$ between post-GDM and control women, but the post-GDM women displayed lower $\beta$-cell function as shown by the lower HOMA (\%B) and the borderline-lower AIR . Although there was no statistically significant difference in BMI between the South Asian GDM and their control group, after adjusting for BMI, differences in 
Table 4. Comparison of clinical, baseline biochemical data and parameters derived from the HOMA model and the FSIVGTT in Afro-Caribbean women with a history of GDM and control subjects.

\begin{tabular}{|c|c|c|c|c|c|}
\hline & $\begin{array}{l}\text { Post- GDM } \\
\quad(\mathbf{n}=10)\end{array}$ & $\begin{array}{l}\text { Control women } \\
(n=19)\end{array}$ & p-value & $\begin{array}{l}\text { p-value with } B M \\
\text { as covariate }\end{array}$ & $\begin{array}{l}\text { p-value with BMI, } \\
\text { age, parity and time } \\
\text { since delivery } \\
\text { as covariates }\end{array}$ \\
\hline $\begin{array}{l}\mathrm{BMI} \\
\left(\mathrm{kg} / \mathrm{m}^{2}\right)\end{array}$ & $\begin{array}{c}28.6 \\
(22.7-36.0)\end{array}$ & $\begin{array}{c}28.3 \\
(24.7-32.5)\end{array}$ & 0.910 & & \\
\hline Waist/Hip ratio & $\begin{array}{c}0.89 \\
(0.77-1.04)\end{array}$ & $\begin{array}{c}0.77 \\
(0.71-0.83)\end{array}$ & 0.013 & $<0.0001$ & $<0.0001$ \\
\hline $\begin{array}{l}\text { F. Cholesterol } \\
(\mathrm{mmol} / \mathrm{l})\end{array}$ & $\begin{array}{c}4.6 \\
(3.7-5.8)\end{array}$ & $\begin{array}{c}4.4 \\
(3.6-5.2)\end{array}$ & 0.449 & 0.407 & 0.478 \\
\hline $\begin{array}{l}\text { F. Triglycerides } \\
(\mathrm{mmol} / \mathrm{l})\end{array}$ & $\begin{array}{c}0.7 \\
(0.5-1.2)\end{array}$ & $\begin{array}{c}0.6 \\
(0.5-0.7)\end{array}$ & 0.333 & 0.232 & 0.250 \\
\hline $\begin{array}{l}\text { F. HDL-Cholesterol } \\
(\mathrm{mmol} / \mathrm{l})\end{array}$ & $\begin{array}{c}1.0 \\
(0.4-2.2)\end{array}$ & $\begin{array}{c}1.2 \\
(1.0-1.6)\end{array}$ & 0.364 & 0.234 & 0.270 \\
\hline $\begin{array}{l}\text { F. Glucose } \\
(\mathrm{mmol} / \mathrm{l})\end{array}$ & $\begin{array}{c}5.2 \\
(4.6-5.8)\end{array}$ & $\begin{array}{c}5.0 \\
(4.7-5.3)\end{array}$ & 0.368 & 0.257 & 0.237 \\
\hline $\begin{array}{l}\text { F. Insulin } \\
(\mathrm{pmol} / \mathrm{l})\end{array}$ & $\begin{array}{c}58 \\
(20-169)\end{array}$ & $\begin{array}{c}93 \\
(33-264)\end{array}$ & 0.270 & 0.269 & 0.297 \\
\hline $\begin{array}{l}\beta \text {-cell function-HOMA model } \\
(\% \mathrm{~B})\end{array}$ & $\begin{array}{c}104 \\
(54-202)\end{array}$ & $\begin{array}{c}152 \\
(73-316)\end{array}$ & 0.179 & 0.200 & 0.107 \\
\hline $\begin{array}{l}\text { Insulin sensitivity-HOMA model } \\
(\% \mathrm{~S})\end{array}$ & $\begin{array}{c}79 \\
(28-221)\end{array}$ & $\begin{array}{c}55 \\
(18-135)\end{array}$ & 0.268 & 0.260 & 0.163 \\
\hline $\begin{array}{l}\mathrm{S}_{\mathrm{i}} \\
\left(10^{4} / \mathrm{min} / \mathrm{pmol} / \mathrm{l}\right)\end{array}$ & $\begin{array}{c}0.4 \\
(0.1-3.0)\end{array}$ & $\begin{array}{c}0.6 \\
(0.1-3.2)\end{array}$ & 0.619 & 0.615 & 0.579 \\
\hline $\begin{array}{l}S_{g} \\
\left(10^{-2} / \min \right)\end{array}$ & $\begin{array}{c}0.9 \\
(0.1-10.9)\end{array}$ & $\begin{array}{c}1.4 \\
(0.1-25.9)\end{array}$ & 0.690 & 0.722 & 0.870 \\
\hline $\begin{array}{l}\mathrm{K}_{\mathrm{g}} \\
\left(10^{-2} / \mathrm{min}\right)\end{array}$ & $\begin{array}{c}1.3 \\
(0.6-2.8)\end{array}$ & $\begin{array}{c}2.6 \\
(1.8-3.8)\end{array}$ & 0.003 & 0.003 & 0.006 \\
\hline $\begin{array}{l}\mathrm{AIR}_{\mathrm{g}} \\
(\mathrm{pmol} / \mathrm{lh})\end{array}$ & $\begin{array}{c}869 \\
(392-1929)\end{array}$ & $\begin{array}{c}1664 \\
(644-4296)\end{array}$ & 0.067 & 0.086 & 0.094 \\
\hline Disposition index & $\begin{array}{c}0.04 \\
(0.01-0.24)\end{array}$ & $\begin{array}{c}0.09 \\
(0.01-0.83)\end{array}$ & 0.308 & & \\
\hline
\end{tabular}

F: Fasting, $\mathrm{S}_{\mathrm{i}}$ : Insulin sensitivity, $\mathrm{S}_{\mathrm{g}}$ : Glucose effectiveness, $\mathrm{K}_{\mathrm{g}}$ : Glucose disappearance rate, AIR $\mathrm{g}$ : Acute insulin response to glucose Data are presented as geometric mean (SD range).

$\operatorname{HOMA}(\% \mathrm{~B})$ and $\mathrm{AIR}_{\mathrm{g}}$ became suggestive of lower $\beta$-cell function. Among the Afro-Caribbean women no significant difference in insulin sensitivity or $\beta$-cell function was identified, but subtle defects in glucose tolerance were noted, as suggested by the lower $\mathrm{K}_{\mathrm{g}}$, derived by the FSIVGTT in the GDM group.

Previous studies examining insulin action and secretion in normoglycaemic women with a history of GDM using different methodologies have shown a range of metabolic defects: defective insulin secretion with intact insulin action, ${ }^{28,29}$ similarly to our South
Asian group; intact insulin secretion postpartum (although decreased during pregnancy) with defective insulin action $;^{30}$ defective insulin secretion with a concomitant defect in insulin action only in an obese subgroup $;{ }^{9}$ and defects in both insulin action and secretion, ${ }^{10,11,31,32}$ similarly to our European group. In many studies, ethnicity of studied subjects has not been clearly stated, ${ }^{9,10,28,29,31,33}$ or mixed populations have been used. ${ }^{30}$ Xiang et al in a larger study, using both the glucose clamp technique and the FSIVGTT, identified defects in both insulin action 


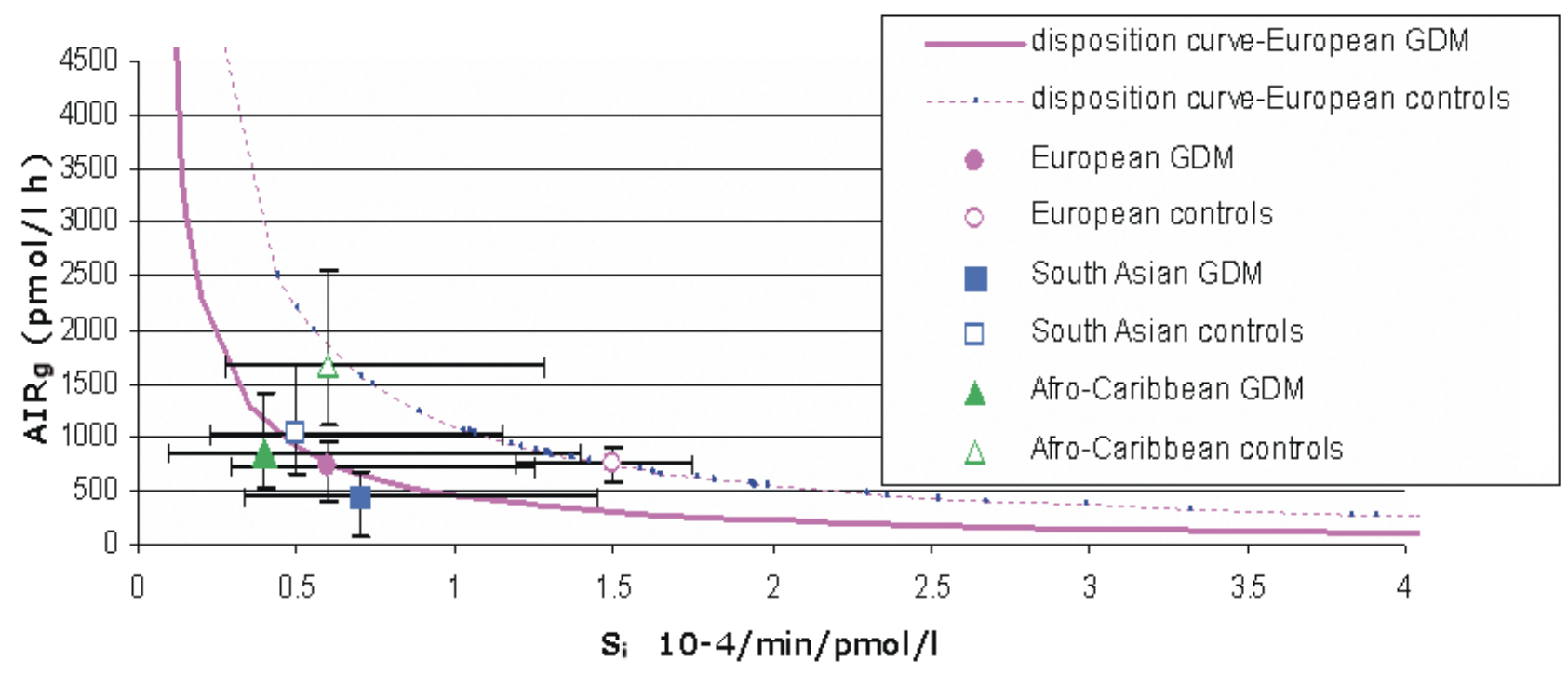

Figure 1. This figure shows a plot of the geometric mean (95\% C.I. of the geometric mean) of the AIR $\mathrm{g}_{\mathrm{g}}$ versus $\mathrm{S}_{\mathrm{i}}$ for each ethnic group. The disposition curve is also shown for the larger European dataset. Although the disposition index $\left(S_{\mathrm{i}} \mathrm{X}\right.$ AIR $\left.\mathrm{g}\right)$ is significantly lower only among the GDM European women compared to the control group, the tendency is similar in the other two ethnic groups.

and secretion in 116 Latino women with previous GDM compared with 25 control women. ${ }^{11}$ However, recent ethnic admixture is marked in such populations, so these results may also have been affected by ethnic heterogeneity.

There is evidence of marked variation in metabolic profile between different ethnic groups. ${ }^{4,6,734-36} \mathrm{Com}$ pared to European subjects, for example, AfricanCaribbean, South Asian and Hispanic populations are generally more insulin resistant $t^{7,35,36}$ and have higher prevalences of $\mathrm{GDM}^{4,5}$ and accelerated progression from GDM to type 2 diabetes. ${ }^{2,6}$ In our own dataset, indexes of the metabolic syndrome were more common among South Asian and African-Caribbean women following gestational diabetes compared with European women. ${ }^{37}$ Given these ethnic differences in both the frequency of GDM and in relevant intermediate traits, it is clear that failure to match study groups for ethnic composition could significantly confound results.

Our study extends previous research in this area, since we restricted recruitment of patients and controls to women of exclusively European, South Asian and Afro-Caribbean origin for three generations to minimise the adverse consequences of ethnic heterogeneity. The predominant metabolic feature in our study among women with a history of GDM is $\beta$-cell dysfunction with variable insulin resistance. Given the differences in the metabolic traits observed following GDM between ethnic groups, it cannot be excluded that slightly different mechanisms may be involved in the development of the metabolic syndrome and diabetes in the various ethnic groups. A limitation of our study is the smaller number of subjects investigated among the South Asian and Afro-Caribbean compared to the European group, and therefore type 2 error cannot be excluded when considering differences between GDM and control women of these non-European ethnic groups.

Our study has the advantage of using a specific and sensitive ELISA, which measures intact insulin only and does not cross-react with proinsulin or split proinsulin products, whereas the radioimmunoassays used in many previous studies measure all immunoreactive insulin molecules. ${ }^{24}$ Given that plasma concentrations of proinsulin and split proinsulin products are raised in type 2 diabetes and in prediabetic states, ${ }^{38,39}$ measurement of specific insulin has clear advantages.

In conclusion, women with a history of GDM of three different ethnic group, even when they have normal fasting glucose, display a range of metabolic 
abnormalities, including $\beta$-cell dysfunction with variable insulin resistance. Differences in the metabolic traits between ethnic groups were also observed, suggesting that slightly different mechanisms may be involved in the process of developing the metabolic syndrome and/or diabetes in the various ethnic groups. Identification of robust markers predictive of future diabetes risk may be of value in determining which women with a history of GDM need the most intensive follow-up for the detection and prevention of future metabolic abnormalities.

\section{ACKNOWLEDGEMENTS}

We are grateful to Dr A. Dornhorst, Dr S. Vijayaraghavan, Prof. A. Hattersley, Dr C. Baynes, Dr C. Johnston, Prof. M. de Swiet, Prof. P.J. Steer, Dr Ana Grenfell, Dr H.M. Mather, Ms Zoë Penn, Ms N. Mahadevan, Ms Judy Harvey, Ms Kate Kiely, Ms Fiona Pullen, Ms Molly Nanka-Bruce, Ms D. Walker, Ms J. Cardon, Dr P. Watkins, Professor S. Amiel and Professor L. Regan for help in patient recruitment and to Alec Sanderson (HICOM, Surrey, UK) and the Diabetic UK for database design. IS-CIBA computer package was kindly provided by Gunther Mehring, Novartis Pharmaceuticals, Basel, Switzerland.

\section{REFERENCES}

1. Johnston DG, Beard RW, Chan SP, et al, 1995 Aspects of metabolism in normal and gestational diabetic pregnancy. Biochem Soc Trans 23: 512-516.

2. O'Sullivan JB, 1991 Diabetes mellitus after GDM. Diabetes 40: Suppl 2: 131-135.

3. Damm P 1996 Diabetes following gestational diabetes mellitus. In: Dornhorst A, Hadden DR (eds) Diabetes and Pregnancy, Chichester, UK; pp, 341-350.

4. Dornhorst A, Paterson CM, Nicholls JS, et al, 1992 High prevalence of gestational diabetes in women from ethnic minority groups. Diabet Med 9: 820-825.

5. Ben-Haroush A, Yogev Y, Hod M, 2004 Epidemiology of gestational diabetes mellitus and its association with Type 2 diabetes. Diabet Med 21: 103-113.

6. Henry OA, Beischer NA, Sheedy MT, Walstab JE, 1993 Gestational diabetes and follow-up among immigrant Vietnam-born women. Aust N Z J Obstet Gynaecol 33: 109-114.

7. McKeigue PM, Shah B, Marmot MG, 1991 Relation of central obesity and insulin resistance with high diabetes prevalence and cardiovascular risk in South Asians. Lancet 337: 382-386.
8. Chaturvedi N, McKeigue PM, Marmot MG, 1994 Relationship of glucose intolerance to coronary risk in AfroCaribbeans compared with Europeans Diabetologia 37: 765-72.

9. Ward WK, Johnston CL, Beard JC, Benedetti TJ, Porte DJr, 1985 Abnormalities of islet B-cell function, insulin action, and fat distribution in women with histories of gestational diabetes: relationship to obesity. J Clin Endocrinol Metab 61: 1039-1045.

10. Ryan EA, Imes S, Liu D, et al, 1995 Defects in insulin secretion and action in women with a history of gestational diabetes. Diabetes 44: 506-512.

11. Xiang AH, Peters RK, Trigo E, Kjos SL, Lee WP, Buchanan TA, 1999 Multiple metabolic defects during late pregnancy in women at high risk for type 2 diabetes. Diabetes 48: 848-854.

12. Kousta E, Lawrence NJ, Godsland IF, et al, 2003 Insulin resistance and beta-cell dysfunction in normoglycaemic European women with a history of gestational diabetes. Clin Endocrinol 59: 289-297.

13. Report of The World Health Organization: Definition, Diagnosis and Classification of Diabetes Mellitus and its Complications, 1999 WHO.

14. Kousta E, Lawrence NJ, Anyaoku V, Johnston DG, McCarthy MI, 2001 Prevalence and features of pancreatic islet-cell autoimmunity in women with gestational diabetes from different ethnic groups. Br J Obstet Gynaecol 108: 716-720.

15. O'Sullivan JB, Mahan CM, Charles D, Dandrow RV, 1973 Screening criteria for high-risk gestational diabetic patients. Am J Obstet Gynecol 116: 895-900.

16. Bergman RN, Prager R, Volund A, Olefsky JM, 1987 Equivalence of the insulin sensitivity index in man derived by the minimal model method and the euglycemic glucose clamp. J Clin Invest 79: 790-800.

17. Saad MF, Andersonm RL, Laws A, et al, 1994 A comparison between the minimal model and the glucose clamp in the assessment of insulin sensitivity across the spectrum of glucose tolerance. The Insulin Resistance Atherosclerosis Study. Diabetes 43: 1114-1121.

18. Chen M, Porte D Jr, 1976 The effect of rate and dose of glucose infusion on the acute insulin response in man. $\mathrm{J}$ Clin Endocrinol Metab 42: 1168-1175.

19. Bergman RN, Phillips LS, Cobelli C, 1981 Physiologic evaluation of factors controlling glucose tolerance in man: measurement of insulin sensitivity and beta-cell glucose sensitivity from the response to intravenous glucose. $\mathrm{J}$ Clin Invest 68: 1456-1467.

20. Kahn SE, Prigeon RL, McCulloch DK, et al, 1993 Quantification of the relationship between insulin sensitivity and beta-cell function in human subjects. Evidence for a hyperbolic function. Diabetes 42: 1663-1672.

21. Matthews DR, Hosker JP, Rudenski AS, Naylor BA, Treacher DF, Turner RC, 1985 Homeostasis model assessment: insulin resistance and beta-cell function from fasting plasma glucose and insulin concentrations in man. 
Diabetologia 28: 412-419.

22. Hermans MP, Levy JC, Morris RJ, Turner RC, 1999 Comparison of insulin sensitivity tests across a range of glucose tolerance from normal to diabetes. Diabetologia 42: 678-687.

23. Hermans MP, Levy JC, Morris RJ, Turner RC, 1999 Comparison of tests of beta-cell function across a range of glucose tolerance from normal to diabetes. Diabetes 48: 1779-1186.

24. Anyaoku V, Johnston DG, 1995 Rapid, specific and sensitive enzyme-linked immunosorbent assay for intact human insulin (Abstract). Diabetalogia 38: Suppl 1: A157.

25. Buchanan TA, Xiang A, Kjos SL, et al, 1998 Gestational diabetes: antepartum characteristics that predict postpartum glucose intolerance and type 2 diabetes in Latino women. Diabetes 47: 1302-1310.

26. Buchanan TA, Xiang AH, Kjos SL, Trigo E, Lee WP, Peters RK, 1999 Antepartum predictors of the development of type 2 diabetes in Latino women 11-26 months after pregnancies complicated by gestational diabetes. Diabetes 48: 2430-2436.

27. Yang YJ, Youn JH, Bergman RN, 1987 Modified protocols improve insulin sensitivity estimation using the minimal model. Am J Physiol 25: E595-602.

28. Efendic S, Hanson U, Persson B, Wajngot A, Luft R, 1987 Glucose tolerance, insulin release, and insulin sensitivity in normal-weight women with previous gestational diabetes mellitus Diabetes 36: 413-419.

29. Dornhorst A, Edwards SG, Nicholls JS, et al, 1991 A defect in insulin release in women at risk of future non-insulindependent diabetes. Clin Sci (Colch) 81: 195-199.

30. Homko C, Sivan E, Chen X, Reece EA, Boden GJ, 2001 Insulin secretion during and after pregnancy in patients with gestational diabetes mellitus. J Clin Endocrinol Metab 86: 568-573.
31. Kautzky-Willer A, Prager R, Waldhausl W, et al, 1997 Pronounced insulin resistance and inadequate beta-cell secretion characterize lean gestational diabetes during and after pregnancy. Diabetes Care 20: 1717-1723.

32. Pimenta WP, Calderon IM, Cruz NS, Santos ML, Aragon FF, Padovani CR, 2004 Subclinical abnormalities of glucose metabolism in Brazilian women with a history of gestational diabetes mellitus. Acta Obstet Gynecol Scand 83: 1152-1158.

33. Damm P, Kuhl C, Hornnes P, Molsted-Pedersen L, 1995 A longitudinal study of plasma insulin and glucagon in women with previous gestational diabetes. Diabetes Care 18: 654-665.

34. Dornhorst A, Chan SP, Gelding SV, et al, 1992 Ethnic differences in insulin secretion in women at risk of future diabetes. Diabet Med 9: 258-262.

35. Haffner SM, D’Agostino R, Saad MF, et al, 1996 Increased insulin resistance and insulin secretion in nondiabetic African-Americans and Hispanics compared with nonHispanic whites. The Insulin Resistance Atherosclerosis Study. Diabetes 45: 742-748.

36. Zoratti R, Godsland IF, Chaturvedi N, et al, 2000 Relation of plasma lipids to insulin resistance, nonesterified fatty acid levels, and body fat in men from three ethnic groups: relevance to variation in risk of diabetes and coronary disease. Metabolism 49: 245-252.

37. Kousta E, Efstathiadou Z, Lawrence NJ, et al, 2006 The impact of ethnicity on glucose regulation and the metabolic syndrome following gestational diabetes. Diabetologia 49: 36-40.

38. Temple R, Clark PM, Hales CN, 1992 Measurement of insulin secretion in type 2 diabetes: problems and pitfalls. Diabet Med 9: 503-512.

39. Hales CN, Byrne CD, Petry CJ, Wareham NJ, 1996 Measurement of insulin and proinsulin. Diabetes Rev 4: 320-335. 